\title{
Chemoselective Synthesis of Isomerical Pair of $(E),(Z)$-Mono-sulfones and Bis-sulfones
}

\author{
A. B. V. Kiran Kumar, ${ }^{\ddagger}$ K. S. V. Krishna Rao, M. Maheswara, ${ }^{\ddagger}$ M. C. S. Subha, ${ }^{\ddagger}$ \\ Shengyun Cui, Dongri Jin, and Yong-Ill Lee* \\ Department of Chemistry, Changwon National University, Changwon. Korea. 'E-mail: wilee(alchangwonackr' \\ ${ }^{\dagger}$ Departmen of Chemistry, Sri Krishadevarava University, Anantapur, India \\ ־Department of Adwanced Materials for Information and Displan, Pusan National Universin: Busan 609-735. Korea \\ Received May 28,2008
}

Key Words : E,Z-Mono-sulfones, Bis-sulfones, Isomerisation, Chenıoselectivity

Organosulfur compounds containing sultides, sulfoxides, and sulfones are important group of heterocyclic compounds, because of their wide range of biological and pharmacological activities such as insecticidal, scabicidal, anti-ulcer, anti-leprosy, anti-tumor, fungicidal and purgative properties. ${ }^{1-5}$ Their properties turn organosulfiur compounds very interesting targets to organic chemists and several strategies for their synthesis were already developed. Organosultur compounds can be synthesized by various methods for example, the addition of thiols to acetylene was considered as an important route for the preparation of $\alpha, \beta$-ethylenic sultones $^{6}$ and their $Z$-isomers. ${ }^{7}$ The addition of benzylthiols with phenyl acetylene has been utilized to obtain Z-styrylbenzylsulfones, ${ }^{8} Z$-styryl thioacetic acid, and it's esters by the trans-addition rule. ${ }^{9}$ Idosufonization of 1 -alkynes were found to be the useful intermediates for the stereoselective preparation of $Z$-vinyl and $Z$-allyl sulfones. ${ }^{\text {ii }}$ However, alkoxy carbonyl vinylsulfones were usually synthesized by refluxing in the presence of organic solvents and reagents. ${ }^{11}$ $E$ - $\gamma$-Hydroxy $\alpha, \beta$-unsaturated sulfones can be obtained selectively by reacting enolizable aldehydes with $p$-tolylsulfinyl methylphenyl sulfones. ${ }^{12}$ In addition, $\alpha, \beta$-unsaturated sulfones and sulfoxides were synthesized in the presence of molybdenum and ruthenium precatalysts via crossmetathesis. ${ }^{13,14}$ Recently the preparation of $(E)$ and $(Z)$-isomers and their corresponding sulphones from $p$-chlorophenylphenylacetylene were reported. ${ }^{15}$ In the present investigation we address a new method for the synthesis of both containing $(E)$ and $(Z$ ) mono-sulfones and bis-sultones from 1-(4-methoxyphenyl)-2-phenyl ethanone.
Compound (A) was treated with thiophenol in the presence of anhydrous $\mathrm{AlCl}_{3}$ and a mixture of both $(E)$-1-(4methoxyphenyl)-2-phenyl-1-(phenylthio)-ethene $(1 E)$ and (Z)-1-(4-methoxyphenyl)-2-phenyl-1-(phenylthio)-ethene (2Z). These compounds are separated on the basis of solubility using $n$-Heptane and purified by column chromatography. The formation of products indicates that the reaction proceeds in a chemoselective manner. On bromination of compound $1 E$ or $2 Z$, they undergo chemoselection to furnish a mixture containing both isomers $(E)$ and $(Z)$-1-bromo-2(4-methoxyphenyl)-1-phenyl-2-(phenylthio)-ethenes ( $3 E$ and $4 Z$ ). The resulting isomers are easily separated by using ethanol; this reaction is represented by Scheme $1 .^{15}$

Compound $3 \boldsymbol{E}$ were treated with $30 \% \mathrm{H}_{2} \mathrm{O}_{2}$ in the presence of acetic acid, this was refluxed for 2-3 $h$ to afford $82 \%$ yield of ( $E$ )-1-bromo-2-(4-methoxyphenyl)-1-phenyl2-(phenylsulfonyl)-ethene $(5 E)$. Compound $5 E$ when treated with sodiumbenzenethiolate in dry ethanol, the colorless (E)-1-(4-methoxyphenyl)-2-phenyl-1-(phenylsulfonyl)-2(phenylthio)-ethene ( $7 E$ ) was obtained with an yield of $70 \%$. On oxidation of compound $7 \boldsymbol{E}$ with $30 \% \mathrm{H}_{2} \mathrm{O}_{2}$ to afford $78 \%$ yield of (E)-1,2-bis-(phenylsulfonyl)-1-(4-methoxyphenyl)-2-(phenyl)-ethene $(9 E)$ in the corresponding product as shown in Scheme 2 .

Similarly, the reaction of the Scheme 3 was carried out under the same conditions for the synthesis of $(Z)$-1-bromo2-(4-methoxyphenyl)-1-phenyl-2-(phenylsulfonyl)-ethene (6Z), (Z)-1-(4-methoxyphenyl)-2-phenyl-1-(phenylsultonyl)-2-(phenylthio)-ethene $(\mathbf{8 Z}),(Z)-1,2$-bis (phenylsulfonyl)1-(4-methoxyphenyl)-2-(phenyl)-ethene (10Z).

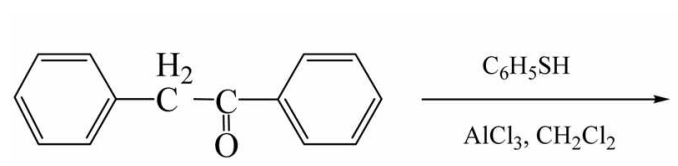

(A)

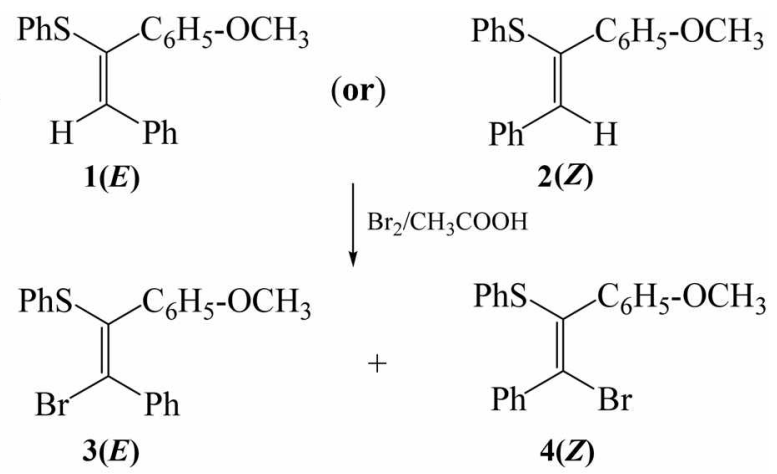

Scheme 1 


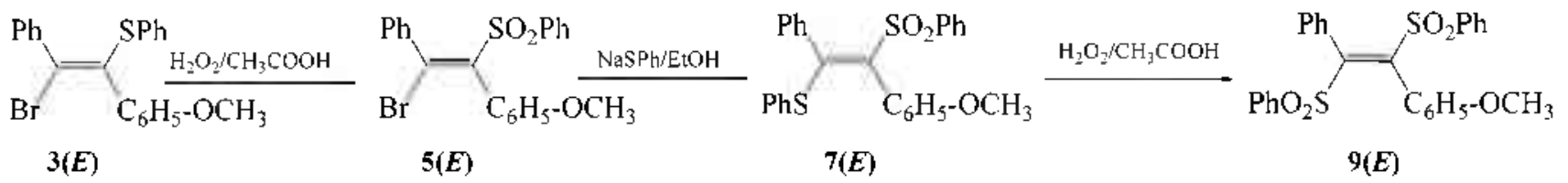

Scheme 2

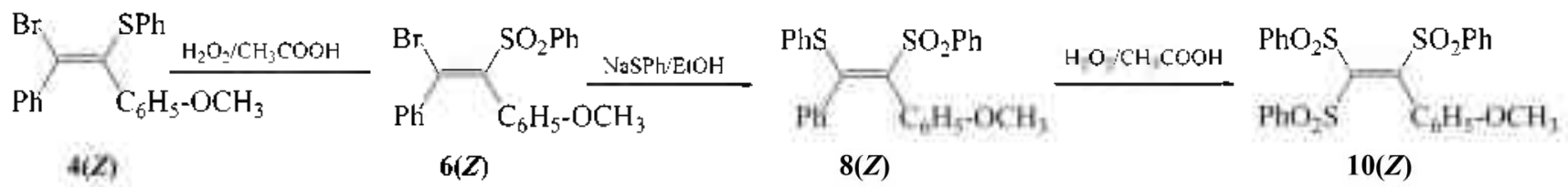

Scheme 3<smiles>COOCCCCC(C(Br)=C(Br)c1ccccc1)=C(Br)c1ccccc1</smiles>

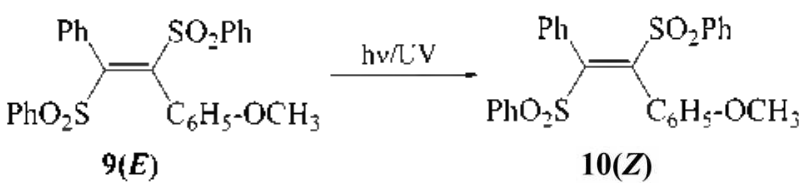

Scheme 4

For the conversion of $E$-isomer to $Z$-isomer about $1 \mathrm{~g}$ of compound $3 E$ was taken in $500 \mathrm{~mL}$ of benzene and the resulting solution was irradiated with UV rays for $20 \mathrm{~h}$. After evaporation of solvent under reduced pressure, the residue was chromatographed on silica gel to afford $75 \%$ yield of $Z$ isomer and it's b.p. $180-181^{\circ} \mathrm{C} ; \lambda_{\text {max }} 307,230,204$ $\mathrm{nm}$; identified as (Z)-1-bromo-2-(4-methoxyphenyl)-1-phenyl-2-(phenylthio)-ethene (4Z). Similar procedure used for (E)-1,2-bis-(phenylsulfonyl)-1-(4-methoxyphenyl)-2-(phenyl)-ethene $(9 E)$ isomerised to (Z)-1,2-bis-(phenylsulfonyl)1-(4-methoxyphenyl)-2-(phenyl)-ethene (10Z) m.p. 203-205 ${ }^{\circ} \mathrm{C} ; \lambda_{\max } 259,223,205 \mathrm{~nm} ; 9 E$; m.p. $191-192{ }^{\circ} \mathrm{C} ; \lambda_{\min } 251$. $207 \mathrm{~nm} ; 10 Z$. The reaction sequence is shown in Scheme 4 .

The $E$-isomers absorbed slightly longer wavelength than the corresponding $Z$-isomers, it may be attributed to the steric crowding and steric inhibition of resonance in crystal lattice of the corresponding $Z$-isomer. When bulky groups are on the same side of the ethylinic double bond, there may be repulsion between the non bonding electrons on the non bonded atoms or repulsion between two bulky benzene moieties. As a consequence of steric repulsion, the two bulky benzene groups are not coplanar and the molecules can not have planar configuration, as a result, the existed state of the molecule has higher energy and its life time also decreases when compared to the planar $E$-isomer. These compounds exhibited UV region, shows longer wave length band around 250-275 $\mathrm{nm}$ and a second band occurred around $207-225 \mathrm{~nm}$. This may be attributed to hyposchromic shift of the longer wave length band from $310-320 \mathrm{~nm}$ to $250-275 \mathrm{~nm}$. The loss of vibrational fine structure and hyposchromic shift of the longer wave length band may be due to the interference of groups, which prevent the conjugated system from assuming a planar configuration. The structures of the products were established from their spectral (UV, IR, ${ }^{1} \mathrm{H}$ NMR and MS) data given below.

\section{Experimental Section}

General procedure for the synthesis of both $\mathrm{E}$ and $\mathrm{Z}$ isomers:

$(E)$ and (Z)-1-(4-methoxyphenyl)-2-phenyl-1-(phenylthio)-ethenes ( $1 E$ and $2 Z$ ). A solution of $50 \mathrm{mmol}$ of 1-(4methoxyphenyl-2-phenyl ethanone and $125 \mathrm{mmol}$ of thiophenol in $100 \mathrm{~mL}$ of $\mathrm{CH}_{2} \mathrm{Cl}_{2}$ was taken in a round-bottomed flask, fitted with an air condenser guarded with a calcium chloride tube. The solution was stirred at room temperature and $17 \mathrm{mmol}$ anhydrous $\mathrm{AlCl}_{3}$ was added over a period of 10 minutes, stirring was continued for another 30 minutes and was then poured into $75 \mathrm{~mL}$ of water. The resulting mixture was extracted with $100 \mathrm{~mL}$ of $\mathrm{CH}_{2} \mathrm{Cl}_{2}$. The aqueous layer was washed with brine $(2 \times 10 \mathrm{~mL})$, dried over anhydrous $\mathrm{MgSO}_{4}$, and the solvent was evaporated to give light yellow oil. This was treated with $n$-heptane and the solid was separated by filtration and recrystallized from acetic acid to yield $45 \%$ of $(E)-1$-(4-methoxyphenyl)-2phenyl-1-(phenylthio)-ethene $(1 E)$. m.p. $72-74^{\circ} \mathrm{C}$. Then the filtrate was evaporated to yield $40 \%$ of (Z)-1-(4-methoxyphenyl)-2-phenyl-1-(phenylthio)-ethene $(2 Z)$ as yellow liquid. Compounds $1 E$ and $2 Z$ were purified by flash chromatography on silica gel.

Compound $1 E$ : m.p. $72-74^{\circ} \mathrm{C}$; $\lambda_{\text {nax }}, 317,225,203 \mathrm{~nm}$; IR (KBr) $1673(\mathrm{C}=\mathrm{C}), 1090(\mathrm{~S}-\mathrm{Ar}) \mathrm{cm}^{-1} ;{ }^{1} \mathrm{H}$ NMR $(200 \mathrm{MHz}$, $\left.\mathrm{CDCl}_{3}\right) \delta: 3.76\left(\mathrm{~s}, 3 \mathrm{H}, \mathrm{CH}_{3}\right), 6.38(\mathrm{~s}, 1 \mathrm{H}, \mathrm{C}=\mathrm{C}-\mathrm{H}), 6.83-7.14$ (m, 5H, Ar-H), 7.16-7.39 (m, 5H, Ar-H), 7.56-7.60 (d, 2H, Ar-H), 7.62-7.94 (d, 2H, Ar-H); LCMS: $m / z 318[\mathrm{M}]^{-}$. Anal. Calcd for $\mathrm{C}_{21} \mathrm{H}_{18} \mathrm{OS}: \mathrm{C}, 79.21 ; \mathrm{H}, 5.7 ; \mathrm{S}, 10.07 \%$. Found: $\mathrm{C}$, $79.18 ; \mathrm{H}, 5.48 ; \mathrm{S}, 9.84 \%$.

Compound $2 Z$ : b.p. $195-197^{\circ} \mathrm{C}$; $\lambda_{\text {max }}, 308,230,204 \mathrm{~nm}$; IR (KBr) $1636(\mathrm{C}=\mathrm{C}), 1083(\mathrm{~S}-\mathrm{Ar}) \mathrm{cm}^{-1} ;{ }^{1} \mathrm{H}$ XMR $(200$ $\left.\mathrm{MHz}, \mathrm{CDCl}_{3}\right\} \delta: 3.74\left(\mathrm{~s}, 3 \mathrm{H}, \mathrm{CH}_{3}\right), 6.55(\mathrm{~s}, 1 \mathrm{H}, \mathrm{C}=\mathrm{C}-\mathrm{H})$, 6.77-6.15 (m, 5H, Ar-H) 7.21-7.32 (m, 5H, Ar-H), 7.57. $7.61(\mathrm{~d}, 2 \mathrm{H}, \mathrm{Ar}-\mathrm{H}), 7.70-7.98$ (d, 2H, Ar-H); LCMS: $m / z 318$ 
$[\mathrm{M}]^{+}$. Anal. Calcd for $\mathrm{C}_{21} \mathrm{H}_{18} \mathrm{OS}$; C, 79.21; H, 5.7; S, $10.07 \%$. Found: C, $78.98 ; \mathrm{H}, 5.5 ; \mathrm{S}, 9.86 \%$.

$(E)$ and $(Z)$-1-bromo-2-(4-methoxy phenyl)-1-phenyl-2(phenylthio)-ethenes ( $3 E$ and $4 Z$ ). To the solution of 10 mmol of $1 E$ or $2 Z$ and $100 \mathrm{~mL}$ of glacial acetic acid taken in round-bottomed flask. $10 \mathrm{mmol}$ of bromine in acetic acid was added drop wise over a period of 30 minutes and the stirring was continued for another 30 minutes. The solid was separated by filteration and recrystallized from ethanol to yield $60 \%$ of (Z)-1-bromo-2-(4-methoxyphenyl)-1-phenyl2-(phenylthio)-ethene (4Z). The filtrate was diluted with water to yield $32.3 \%$ of $(E)$-1-bromo-2-(4-methoxyphenyl)1-phenyl-2-(phenylthio)-ethene ( $3 E$ ) as viscous liquid.

Compound $3 E$ : m.p. $125-127^{\circ} \mathrm{C}$; $\lambda_{\max } 312,226,203 \mathrm{~nm}$; IR (KBr) $1682(\mathrm{C}=\mathrm{C}), 1080$ (S-Ar) $\mathrm{cm}^{-1} ;{ }^{1} \mathrm{H}$ XMR (200 $\left.\mathrm{MHz}, \mathrm{CDCl}_{3}\right) \delta: 3.73\left(\mathrm{~s}, 3 \mathrm{H}, \mathrm{CH}_{3}\right), 6.63-7.10(\mathrm{~m}, 5 \mathrm{H}, \mathrm{Ar}-\mathrm{H})$, 7.16-7.36 (m, 5H, Ar-H), 7.51-7.52 (d, 2H, Ar-H), 7.95-8.01 (d, 2H, Ar-H); LCMS: $m / z 396\left[\mathrm{M}^{-}\right.$. Anal. Calcd for $\mathrm{C}_{21}$ $\mathrm{H}_{17} \mathrm{BrO}$ S; C. 63.26; H. 4.11; S, 7.85\%. Found: C, 63.26; $\mathrm{H}$. $4.11 ; \mathrm{S}, 7.85 \%$.

Compound 4Z: b.p. $180-181{ }^{\circ} \mathrm{C} ; \lambda_{\text {-nax }} 307,230,204 \mathrm{~nm}$; IR (KBr) $1605(\mathrm{C}=\mathrm{C}), 1075(\mathrm{~S}-\mathrm{Ar}) \mathrm{cm}^{-1} ;{ }^{1} \mathrm{H}$ NMR $(200$ $\left.\mathrm{MHz}, \mathrm{CDCl}_{3}\right) \delta: 3.86\left(\mathrm{~s}, 3 \mathrm{H}, \mathrm{CH}_{3}\right), 6.92-7.12(\mathrm{~m}, 5 \mathrm{H}, \mathrm{Ar}-\mathrm{H})$, 7.15-7.42 (m, 5H, Ar-H), 7.47-7.49 (d, 2H, Ar-H), 7.50-7.51 (d, 2H, Ar-H); LCMS: $m / z 396[\mathrm{M}]^{+}$. Anal. Calcd for $\mathrm{C}_{21} \mathrm{H}_{1}-\mathrm{BrO} \mathrm{S}$; C. 63.48; H, 4.31; S, 8.07\%. Found: $\mathrm{C}, 63.27$; $\mathrm{H}, 4.09, \mathrm{~S}, 7.86 \%$.

(E)-1-Bromo-2-(4-methoxyphenyl)-1-phenyl-2-(phenylsulfonyl)-ethene ( $5 E$ ). A solution of $5 \mathrm{mmol}$ of $3 E$ in $60 \mathrm{~mL}$ of glacial acetic acid was taken in round bottomed flask fitted with a reflux condenser and heated. To this solution 20 $\mathrm{mL}$ of $30 \% \mathrm{H}_{2} \mathrm{O}_{2}$ was added and refluxed for $2 \mathrm{~h}$. The resulting product separated, followed by filtration and recrystallization from ethanol to yield $82 \%$ of $\mathbf{5} \boldsymbol{E}$. Similar procedure was adopted in the synthesis of (Z)-1-bromo-2(4-methoxyphenyl)-1-phenyl-2-(phenylsulfonyl)-ethene (6Z) from $4 Z$.

Compound 5E: m.p. 201-203 ${ }^{\circ} \mathrm{C}$; $\lambda_{\text {max }} 311,217,200 \mathrm{~nm}$; IR (KBr) $1634(\mathrm{C}=\mathrm{C}), 1167 \& 1325$ (S=O), 1088 (S-Ar) $\mathrm{cm}^{-1}$; ${ }^{1} \mathrm{H}$ NMR (200 MHz, CDCl $) \delta: 3.69$ (s, $3 \mathrm{H}, \mathrm{CH}_{3}$ ), 7.14-7.26 (m, 5H, Ar-H), 7.39-7.45 (m, 5H, Ar-H), 7.497.51 (d, 2H, Ar-H), 7.58-7.6 (d, 2H, Ar-H); LCMS: $m / z 430$ [M] $]^{+}$. Anal. Calcd for $\mathrm{C}_{21} \mathrm{H}_{17} \mathrm{BrO}_{3} \mathrm{~S} ; \mathrm{C}, 58.75 ; \mathrm{H}, 3.99 ; \mathrm{S}$. 7.47\%. Found: C. $58.54 ; \mathrm{H}, 3.76, \mathrm{~S}, 7.26 \%$.

Compound 6Z: m.p. $180-182{ }^{\circ} \mathrm{C} ; \lambda_{\max } 305,226,202 \mathrm{~nm}$; IR (KBr) $1630(\mathrm{C}=\mathrm{C}), 1161 \& 1327(\mathrm{~S}=\mathrm{O}), 1078(\mathrm{~S}-\mathrm{Ar})$ $\mathrm{cm}^{-1} ;{ }^{l} \mathrm{H}$ NMR (200 MHz, CDCl $) \delta: 3.72\left(\mathrm{~s}, 3 \mathrm{H}, \mathrm{CH}_{3}\right)$, 7.04-7.18 (m, 5H, Ar-H), 7.29-7.36 (m, 5H, Ar-H), 7.397.41 (d, 2H, Ar-H), 7.48-7.50 (d, 2H, Ar-H); LCMS: $m / z 430$ $[\mathrm{M}]^{+}$. Anal. Calcd for $\mathrm{C}_{21} \mathrm{H}_{17} \mathrm{BrO}_{3} ; \mathrm{C}, 58.75 ; \mathrm{H}, 3.99 ; \mathrm{S}$, 7.47\%. Found: C. 58.56 ; H. 3.84; S. 7.35\%.

(E)-1-(4-Methoxyphenyl)-2-phenyl-1-(phenylsulfonyl)2-phenylthio)-ethene (7E). A solution of $1.30 \mathrm{~g}$ of $(E)-1-$ bromo-2-(4-methoxyphenyl)-1-phenyl-2-(phenylsulfonyl)ethene $(5 E)$ in $160 \mathrm{~mL}$ of dry ethanol was taken in a round bottomed flask fitted with a reflux condenser and guarded with calcium chloride tube. To this reaction solution, Sodi- un benzenethiolate prepared from $69.2 \mathrm{mg}$ ( $3 \mathrm{mg}$ atom) of sodium, $10 \mathrm{~mL}$ of dry ethanol and $0.33 \mathrm{~g}(3 \mathrm{mmol})$ of thiophenol was added. The mixture was refluxed for $7 \mathrm{~h}$, then cooled, and filtered to get colorless product. This was recrystallized from ethanol to yield $70 \%$ of $7 \boldsymbol{E}$. Similar procedure was adopted in the synthesis of (Z)-1-(4-methoxyphenyl)-2-phenyl-1-(phenylsulfonyl)-2-(phenylthio)ethene $(8 Z)$ from $6 Z$.

Compound 7E: m.p. $167-169^{\circ} \mathrm{C} ; \lambda_{\text {max }} 310,238,206 \mathrm{~nm}$; IR (KBr) 1635 (C=C), $1163 \& 1358$ ( $\mathrm{S}=\mathrm{O}), 1094$ (S-Ar) $\mathrm{cm}^{-1} ;{ }^{1} \mathrm{H}$ XMR $\left(200 \mathrm{MHz}, \mathrm{CDCl}_{3}\right) \delta: 3.72\left(\mathrm{~s}, 3 \mathrm{H}, \mathrm{CH}_{3}\right)$, 7.38-7.52 (m, 5H, Ar-H), 7.58-7.69 (m, 5H, Ar-H), 7.717.90 (m, 5H, Ar-H) 7.94-7.95 (d, 2H, Ar-H), 7.96-8.10 (d, $2 \mathrm{H}, \mathrm{Ar}-\mathrm{H}$ ); LCMS: $m / z 458[\mathrm{M}]^{+}$. Anal. Calcd for $\mathrm{C}_{27} \mathrm{H}_{22} \mathrm{O}_{3} \mathrm{~S}_{2}$; C, $70.01 ; \mathrm{H}, 4.84 ; \mathrm{S}, 13.98 \%$. Found: C, 69.9; H, 4.75; S, $13.87 \%$.

Compound 8Z: m.p. $156-157^{\circ} \mathrm{C}$; $\lambda_{\text {max }} 306,201 \mathrm{~nm}$; IR (KBr) $1622(\mathrm{C}=\mathrm{C}), 1162 \& 1363(\mathrm{~S}=\mathrm{O}), 1085(\mathrm{~S}-\mathrm{Ar}) \mathrm{cm}^{-1}$; ${ }^{1} \mathrm{H}$ NMR $\left(200 \mathrm{MHz}, \mathrm{CDCl}_{3}\right) \delta: 3.75$ (s, $\left.3 \mathrm{H}, \mathrm{CH}_{3}\right), 7.29-7.57$ (m, 5H, Ar-H), 7.58-7.71 (m, 5H, Ar-H), 7.79-7.83 (m, 5H, Ar-H) 7.84-7.86 (d, 2H, Ar-H), 7.86-7.91 (d, 2H, Ar-H); LCMS: $m / z 458[\mathrm{M}]^{+}$. Anal. Calcd for $\mathrm{C}_{27} \mathrm{H}_{22} \mathrm{O}_{3} \mathrm{~S}_{2} ; \mathrm{C}, 70.01$; $\mathrm{H}, 4.84 ; \mathrm{S}, 13.98 \%$. Found: $\mathrm{C}, 69.86 ; \mathrm{H}, 4.78 ; \mathrm{S}, 13.86 \%$.

(E)-1,2-Bis-(phenylsulfonyl)-1-(4-methoxyphenyl)-2(phenyl)-ethene $(9 E)$. A solution of $3 \mathrm{mmol}$ of $7 E$ in $70 \mathrm{~mL}$ glacial acetic acid was taken in a round bottomed flask fitted with a reflux condenser and guarded with calcium chloride tube. The solution was heated and to this $15 \mathrm{~mL}$ of $30 \%$ $\mathrm{H}_{2} \mathrm{O}_{2}$ was added, the mixture was refluxed for $1 \mathrm{~h}$, then cooled and filtered to get a colorless product. This was recrystallized from ethanol to yield $78 \%$ of $9 E$. Similar procedure was adopted in the synthesis of $(Z)$-1,2-bis(phenylsulfonyl)-1-(4-methoxyphenyl)-2-(phenyl)-ethene (10Z) from $8 Z$.

Compound $9 E$ : m.p. 203-205 ${ }^{\circ} \mathrm{C}$; $\lambda_{\text {max }} 259,223,205 \mathrm{~nm}$; IR (KBr) 1642 ( $\mathrm{C}=\mathrm{C}), 1149 \& 1322(\mathrm{~S}=\mathrm{O}), 1089$ (S-Ar) $\mathrm{cm}^{-1}$; ${ }^{1} \mathrm{H}$ XMR $\left(200 \mathrm{MHz}, \mathrm{CDCl}_{3}\right) \delta: 3.72$ (s, 3H, $\left.\mathrm{CH}_{3}\right)$, 6.79-7.02 (m, 5H, Ar-H), 7.03-7.17 (m, 5H, Ar-H), 7.23$7.41(\mathrm{~m}, 5 \mathrm{H}, \mathrm{Ar}-\mathrm{H}), 7.42-7.43(\mathrm{~d}, 2 \mathrm{H}, \mathrm{Ar}-\mathrm{H}), 7.55-7.57$ (d, $2 \mathrm{H}$, Ar-H); LCMS: $m / z$ 490 [M] $]^{-}$Anal. Calcd for $\mathrm{C}_{27} \mathrm{H}_{22} \mathrm{O}_{5} \mathrm{~S}_{2} ; \mathrm{C}, 66.10 ; \mathrm{H}, 4.52 ; \mathrm{S}, 13.07 \%$. Found: $\mathrm{C}, 65.98$; $\mathrm{H}, 4.43 ; \mathrm{S}, 12.96 \%$.

Compound 10Z: m.p. 191-192 ${ }^{\circ} \mathrm{C} ; \lambda_{\text {max }} 251,207 \mathrm{~nm}$; IR $(\mathrm{KBr}) 1637(\mathrm{C}=\mathrm{C}), 1142 \& 1317(\mathrm{~S}=\mathrm{O}), 1068(\mathrm{~S}-\mathrm{Ar}) \mathrm{cm}^{-1}$; ${ }^{\mathrm{j}} \mathrm{H}$ NMR $\left(200 \mathrm{MHz}, \mathrm{CDCl}_{3}\right) \delta: 3.73\left(\mathrm{~s}, 3 \mathrm{H}, \mathrm{CH}_{3}\right), 6.91-7.13$ $(\mathrm{m}, 5 \mathrm{H}, \mathrm{Ar}-\mathrm{H}), 7.21-7.38(\mathrm{~m}, 5 \mathrm{H}, \mathrm{Ar}-\mathrm{H}), 7.39-7.48(\mathrm{~m}, 5 \mathrm{H}$, Ar-H) 7.52-7.54 (d, 2H, Ar-H), 7.67-7.72 (d, 2H, Ar-H); LCMS: $m / z 490[\mathrm{M}]^{+}$. Anal. Calcd for $\mathrm{C}_{27} \mathrm{H}_{22} \mathrm{O}_{5} \mathrm{~S}_{2} ; \mathrm{C}, 66.10$; $\mathrm{H}, 4.52 ; \mathrm{S}, 13.07 \%$. Found: $\mathrm{C}, 65.96 ; \mathrm{H}, 4.47 ; \mathrm{S}, 12.98 \%$.

Acknowledgments. The authors gratefully acknowledge the support by the Korea Research Foundation (Grant No. KRF-C00168).

\section{References}

1. Cremlyn, R. J. An Introdtction to Organosulphtr Chemistry; Jolu Wiley \& Sons: Chichester; 1996; Vol. 3, pp 219-233. 
2. Sammes, P. G Contrehensive Medicind Chemistry; Pergamon Press: Oxford, 1990; Vol. 2, pp 225-229.

3. Damani, L. A.; Mitchard, M. Stwfur-contcining Drugs and Related Organic Compounds-Chemistrn Biochemistry and Toxicology; Ellis Horwood: Chichester, 1989; Vol. 1, (Part A), p 92.

4. Weekd epidemiological record (WHO) 2001, 23, 173-179.

5. Müller, A.; Krebs, B. Sulfur It s Significance for Chentist y for the Geo. Bio- \&Coshto-sphere and Technologn; Elsevier: Amsterdam, 1984; p 99 .

6. Kartrizky, A. R.; Afridi, A. S.; Kuznierkiewicz, W. Helv: Chim. Acto 1991, 74, 1931-1935.

7. Peeran, S. G.; Hanumantha Reddy, G. Phosphorts, Sidfitr and Silicon 1990, 54, 9-22.

8. Bhaskar Reddy, D; Ramana Reddy, P. V; Padmavathi, V.;
Ramana Reddy, M. V. Stlfin Lett. 1991, 13,83-89.

9. Bhaskar Reddy, D.; Ramana Reddy, P. V; Vjjayalakshmi, S.; Ramana Reddy, M. V. Phosphoris, Sulfir and Silicon 1993, 84, 63-71.

10. Iwatw, N.; Morioka, T.; Kobayashi, T.: Asada, T.; Kineshita, H.; Inomata, K. Bull. Chem. Soc. Jpn 1992, 65, 1379-1385.

11. Ramachandra Reddy, G; Gupta, S. V. S. A. K.; Bhaskar Reddy, D.; Seenaiah, B. I. Indian Chem. Soc. 1992, 69, 396-341.

12. Dominguez, E.; Carretero, J. C. Tetrahedron 1990, 46, 7197-7204.

13. Grela, K.; Michrowska, A.; Bieniek, M.; Klajan, R. Tetrahedron 2003, 59, 4525-7981.

14. Grela, K.; Bieniek, M. Tetrahedron 2003, 59, 7973-4531.

15. Husain, Md. M.; Shafi, M.; Swami, G. N.; Peeran, S. G. Phosphoris, Sulfir and Silicon 2006, 181, 763-770. 